\title{
Nucleotide receptors as targets in the pharmacological enhancement of dermal wound healing
}

\author{
Edyta Gendaszewska-Darmach • Marta Kucharska
}

Received: 10 December 2010/Accepted: 10 April 2011 /Published online: 26 April 2011

(C) The Author(s) 2011. This article is published with open access at Springerlink.com

\begin{abstract}
With a growing interest of the involvement of extracellular nucleotides in both normal physiology and pathology, it has become evident that P2 receptor agonists and antagonists may have therapeutic potential. The P2Y2 receptor agonists (diquafosol tetrasodium and denufosol tetrasodium) are in the phase 3 of clinical trials for dry eye and cystic fibrosis, respectively. The thienopyridine derivatives clopidogrel and ticlopidine (antagonists of the platelet P2Y12 receptor) have been used in cardiovascular medicine for nearly a decade. Purines and pyrimidines may be of therapeutic potential also in wound healing since ATP and UTP have been shown to have many hallmarks of wound healing factors. Recent studies have demonstrated that extracellular nucleotides take part in all phases of wound repair: hemostasis, inflammation, tissue formation, and tissue remodeling. This review is focused on the potent purines and pyrimidines which regulate many physiological processes important for wound healing.
\end{abstract}

Keywords P2 receptors · Nucleotides · Wound healing · Inflammation $\cdot$ Angiogenesis

$\begin{array}{ll}\text { Abbreviations } \\ \text { CBMCs } & \text { Cord blood mast cells } \\ \text { DCs } & \text { Dendritic cells } \\ \text { ECM } & \text { Extracellular matrix } \\ \text { ECs } & \text { Endothelial cells }\end{array}$

E. Gendaszewska-Darmach $(\bowtie) \cdot$ M. Kucharska Institute of Technical Biochemistry, Faculty of Biotechnology and Food Sciences, Technical University of Lodz, Stefanowskiego 4/10, 90-924 Lodz, Poland e-mail: edarmach@wp.pl

$\begin{array}{ll}\text { EGF } & \text { Epidermal growth factor } \\ \text { EGFR } & \text { Epidermal growth factor receptor } \\ \text { ERK } & \text { Extracellular-signal-regulated kinase } \\ \text { FGF } & \text { Fibroblast growth factor } \\ \text { GPCR } & \text { G protein-coupled receptor } \\ \text { HAECs } & \text { Human aortal endothelial cells } \\ \text { HMVECs } & \text { Human microvessel endothelial cells } \\ \text { HUVECs } & \text { Human umbilical vein endothelial cells } \\ \text { IFN } & \text { Interferon } \\ \text { IGF } & \text { Insulin-like growth factor } \\ \text { IL } & \text { Interleukin } \\ \text { LCs } & \text { Langerhans cells } \\ \text { MAPK } & \text { Mitogen associated protein kinase } \\ \text { MMP } & \text { Metalloproteinase } \\ \text { NHK } & \text { Normal human keratinocytes } \\ \text { PAI } & \text { Plasminogen activator inhibitor } \\ \text { PDGF } & \text { Platelet-derived growth factor } \\ \text { PI3K } & \text { Phosphoinositol 3-kinase } \\ \text { THCE } & \text { SV-40 immortalized human corneal epithelial } \\ & \text { HCE cell line } \\ \text { TGF } & \text { Transforming growth factor } \\ \text { TNF } & \text { Tumor necrosis factor } \\ \text { VEGF } & \text { Vascular endothelial growth factor } \\ \text { VEGFR } & \text { Vascular endothelial growth factor receptor } \\ \text { VSMCs } & \text { Vascular smooth muscle cells } \\ \text { VVEC } & \text { Vasa vasorum endothelial cells } \\ & \end{array}$

\section{Introduction}

Extracellular adenosine 5'-triphosphates and 5'-diphosphates (ATP, ADP) as well as uridine-5'-triphosphate (UTP) and uridine-5'-diphosphate (UDP) have been recognized as important signaling molecules involved in the 
regulation of many cellular processes. Since P2 receptors activated by nucleotides are expressed in nearly all cell types, purines and pyrimidines have a key role in the regulation of a variety of functions in many tissues. Abbracchio and Burnstock, on the basis of molecular structure and transduction mechanisms, divided P2 purinoceptors into two major families: a P2X family of ligand-gated ion channel receptors and a P2Y family of G protein-coupled receptors [reviewed in 1]. The P2X family consists of seven subtypes (P2X1-7), and these form channels made by the assembly of subunit of the same (homo-oligomers) or different (hetero-oligomers) subtypes. For example, heteromultimers are clearly established for $\mathrm{P} 2 \mathrm{X} 2 / 3$ receptors. $\mathrm{P} 2 \mathrm{X} 1 / 2, \mathrm{P} 2 \mathrm{X} 1 / 5, \mathrm{P} 2 \mathrm{X} 2 / 6, \mathrm{P} 2 \mathrm{X} 4 / 6$, and more recently $\mathrm{P} 2 \mathrm{X} 1 / 4$ heteromultimers have also been identified. P2X7 does not form heteromultimers, and P2X6 does not form a functional homomultimer. The stoichiometry of $\mathrm{P} 2 \mathrm{X}(1-7)$ receptors is thought to involve three subunits, which form a stretched trimer or a hexamer of conjoined trimers. cDNA cloning of P2X receptors has revealed that each subunit in this receptors has two membrane-spanning domains (TM1 and TM2), the Ntermini and C-termini are within the cell and the bulk of the receptor protein is extracellular [2]. The P2Y family consists of eight receptors which are divided based on coupling to specific $\mathrm{G}$ proteins, overall sequence similarity and second messenger responses. P2Y receptors consist of seven membrane spanning domains and eight subtypes have been identified: P2Y1, P2Y2, P2Y4, P2Y6, $\mathrm{P} 2 \mathrm{Y} 11, \mathrm{P} 2 \mathrm{Y} 12, \mathrm{P} 2 \mathrm{Y} 13$, and $\mathrm{P} 2 \mathrm{Y} 14$. Whereas P2X receptors tend to be activated principally by adenine nucleotides, $\mathrm{P} 2 \mathrm{Y}$ receptors are activated by adenine and/ or uracil nucleotides. The $\mathrm{P} 2 \mathrm{Y} 1$ receptor responds to ADP > ATP but not to UTP while the P2Y2 receptor responds to both ATP and UTP and the P2Y4 responds to UTP $>$ ATP in humans [3]. The P2Y6 subtype responds preferentially to UDP and has little affinity for ATP and the P2Y11 responds to ATP but not to UTP [4]. P2Y12 [5] and P2Y13 [6] are activated by ADP. P2Y14 is activated by UDP-glucose [7]. The P2Y receptors are unusual in comparison to other cluster of GPCR sequences because they respond to varied and diverse nucleotide ligands. P2Y receptors couple to one or more heterotrimeric $G$ proteins, including $\mathrm{G}_{\mathrm{q} / 11}, \mathrm{G}_{\mathrm{s}}, \mathrm{G}_{\mathrm{i} / \mathrm{o}}$, and $\mathrm{G}_{12 / 13}$ resulting in the activation of various signaling pathways [reviewed in $1,8,9]$.

The majority of studies involving purinergic signaling has been concerning their role in short-term events, such as neurotransmission, secretion, or regulation of the vascular hemostasis. However, there is growing interest in the longterm trophic effects of extracellular nucleotides on cell growth, proliferation, and death. Several studies over the past decade have shown that nucleotides released from damaged tissues also regulate many important functions of skin cells, including proliferation, migration, and contraction.
Short- and long-term effects after injury are mediated by nucleotides and can promote wound healing $[10,11]$. This review is focused on the potent purines and pyrimidines which regulate many physiological processes important for wound healing. The latest findings of application of extracellular nucleotides have indicated that interventions in purinergic signaling might also provide new therapeutic approaches for the treatment of wound healing.

\section{Sources of nucleotides in the wound}

Nucleotides are released from cells by mechanical stimulation, ligand binding, exocytotic release, or injury. The concentration of extracellular nucleotides is low in healthy, non-damaged tissues (e.g., ATP is approximately $10 \mathrm{nM}$ ) despite the cytosolic concentration is very high $(3-10 \mathrm{mM}$ in the case of ATP) [12]. Cell damage, acute cell death, or environmental stimuli (mechanical stress, osmolarity change, and oxidative stress) trigger the release of nucleotides from cells. Cell injury initiates the release of various growth factors in the wound bed as well as it causes an outflow of nucleotides that reaches the range for P2 receptor activation. Epidermis is the skin layer which is exposed to most stimuli activating the release of nucleotides. It consists principally of keratinocytes which are stratified, squamous, epithelial cells of a highly dynamic structure. Dixon et al. have demonstrated that even under static conditions, normal human keratinocytes release ATP reaching concentration of approximately $17 \mathrm{nM}$ [13]. Also, cultures of an immortal $\mathrm{HaCaT}$ keratinocyte cell line release ATP in a cell number-dependent manner [14]. It has also been reported that normal human keratinocyte cultures as well as human keratinocyte A431 cell line release ATP in response to cell damage by irritant chemicals reaching almost $30 \mu \mathrm{M}$ concentration mainly by disrupting membrane lipid bilayers [15]. Yin et al. have observed $\sim 15 \mathrm{nM}$ ATP release from transfected human corneal epithelial (THCE) resting cells (an SV-40 immortalized corneal epithelial HCE cell line) [11]. However, such concentration of ATP are below the range to activate purinoceptors. Scratch wounds of THCE cells have resulted in ATP release from damaged cells into the culture medium $(1.25 \mu \mathrm{M})$. This suggests that in vivo at the moment of cell injury the extracellular ATP concentration reaches the range for $\mathrm{P} 2$ receptor activation. Yin et al. have also demonstrated that extracellular ATP concentration is elevated after wounding in bronchial and intestinal epithelial cells, indicating that injury-caused ATP release might be a common scenario among epithelial cells.

Tissue injury also causes the blood vessel disruption with concomitant extravasation of blood constituents followed by the release of nucleotides from platelets. 
During wounding, one of the first steps is activation of platelets occurring by binding to collagen that becomes exposed following rupture of the endothelial lining of vessels (Fig. 1). Platelet activation is characterized by rapid shape change, release of granular contents, generation of lipid mediators, and aggregation [16]. Dense granules (also called delta-granules or dense bodies) are packed with serotonin, calcium, ATP, ADP, and pyrophosphate. Platelets contain $40 \mathrm{nmol}$ of ATP and ADP per mg of protein. Because concentration of ATP within the storage granules is very high $(\sim 100 \mathrm{mM})$ its plasma concentration at sites of massive platelet aggregation reaches $20-50 \mu \mathrm{M}[17,18]$. ATP and ADP released upon platelet activation act in a positive feedback manner (i.e., activating other resting platelets) thus amplifying the initial response.

Among constituents of blood neutrophils are primary phagocytic cells with important roles in tissue repair. A key feature of neutrophils is their ability to detect and migrate to compromised tissues following a concentration gradient of chemotactic substances released from injured cells. Neutrophils can detect a $1 \%$ difference in the concentration of chemoattractant [19]. Human neutrophils release ATP from the leading edge of the cell surface to amplify chemotactic signals what helps neutrophils locate damaged tissues, which also generate extracellular ATP [20]. Besides platelets and leukocytes erythrocytes are an additional important source of extracellular ATP in the wound. ATP is released from erythrocytes upon exposure to low oxygen tension and mechanical deformation. Sprague et al. reported that both rabbit and human erythrocytes release ATP in response to mechanical deformation [21]. Mechanical deformation can occur as the erythrocyte passes through small resistance vessels and capillaries of the microcirculation or in response to increases in linear flow velocity. Human erythrocytes have also been reported to release ATP in response to decreased oxygen tension [22].

The concentration of extracellular nucleotides is elevated at the site of vascular injury because nucleotides are released not only from activated platelets, neutrophils, or erythrocytes but also from endothelial cells, vascular smooth muscle cells, and fibroblasts which are the main cellular component of the blood vessel wall. It has been shown that even nonlytic stimuli such as increased flow rate cause the increased release of pharmacologically relevant amounts of ATP from endothelial cells [23] and fibroblasts [24]. Bodin et al. have shown that vascular smooth muscle cells (VSMCs) freshly isolated from the rabbit thoracic aorta are unable to release ATP when subjected to increased flow [25]. However, recent data have indicated shown that mechanical stimulation (washes with PBS) triggers rapid release of endogenous ATP and other low molecular mass metabolites into the extracellular compartment in the case of rat vascular smooth muscle cells [26]. Endothelial cells in the vascular system are continuously exposed to mechanical forces due to the pulsatile nature of blood flow and shear stress. During injury, increased shear stress can additionally cause endothelial cell perturbations and the release of a large amount of nucleotides. Since VSMCs and fibroblasts lay underneath the endothelial layer, they are not directly exposed to mechanical shear stress associated with blood flow. However, after the endothelium is disrupted by injury, the latter cells may also be directly exposed to arterial shear stress and they may be modulated by changes in the local hemodynamic environment. Thus these hemodynamic forces play an important role in the regulation of wound healing since mechanical stimuli associated with blood flow play an important role in the regulation of vascular remodeling.

Hypoxia which is associated with tissue damage also contributes to the elevated levels of nucleotide release at the site of injury. Many cell types, including endothelial cells [27], fibroblasts [28], and erythrocytes [22, 29] release ATP in response to hypoxia.

Much less is known about sources and release mechanisms of UTP. However, UTP has been detected in low nanomolar concentrations in the extracellular medium of many cells examined under resting conditions, and enhanced UTP levels has been observed after mechanical stimulation. The concentration of UTP measured in the medium bathing $\sim 3 \times 10^{5}$ tissue culture cells under basal conditions ranges from 1 to $5 \mathrm{nM}$. The ratio of 1:3-5 for

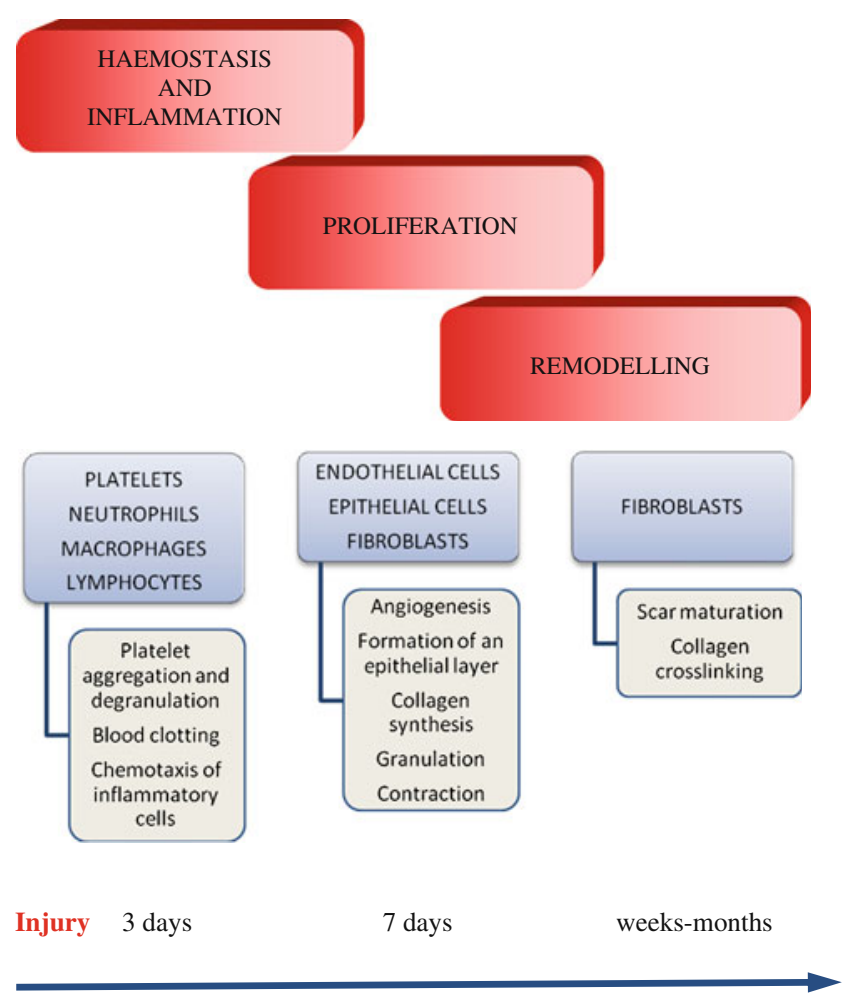

Fig. 1 Cellular events during different stages of wound healing 
extracellular UTP/ATP has been observed in all nonexcitable tissues both in resting and mechanically stimulated conditions, closely reflecting the relative intracellular abundance of these nucleotides. Thus, a common source and perhaps a common mechanism of release may exist for both ATP and UTP [30, 31].

\section{Expression of nucleotide receptors on cells involved in wound healing}

Release of high local concentrations of ATP and UTP activates P2 receptors found at the surface of the skin cells involved in wound healing (Table 1). Since injury causes the release of intracellular nucleotides, the released ATP and UTP can act as a "cell-damage" signal to trigger cell signaling events including $\mathrm{Ca}^{2+}$ waves and G-proteincoupled receptor activation. Reepithelialization is a critical step in wound healing. During this process, keratinocytes, the predominant epidermal cells, exhibit increased proliferation and enhanced migration. P2 receptors are expressed in spatially distinct zones of the epidermis where they may regulate different cellular functions (e.g., P2X5 and P2X7 are preferentially expressed in the stratum spinosum and stratum corneum, respectively, where they promote differentiation) [32]. In situ hybridization has revealed a localization of $\mathrm{P} 2 \mathrm{Y} 2$ receptor transcripts in the basal cell layer of skin sections [13]. In vitro, the expression of mRNA for P2Y1, P2Y2, P2Y4, and P2Y6 receptors has been demonstrated in $\mathrm{HaCaT}$ cells and differentiated and undifferentiated normal human keratinocytes (NHK). However, in NHK, only the P2Y2 receptor subtype seems to be functional and evidence for functional P2Y1, P2Y2, and $\mathrm{P} 2 \mathrm{Y} 4$ receptors in $\mathrm{HaCaT}$ has been confirmed [14]. Yoshida et al. demonstrated that $\mathrm{HaCaT}$ cells express $\mathrm{P} 2 \mathrm{X} 5$ and $\mathrm{P} 2 \mathrm{X} 6$ receptor mRNAs as $\mathrm{P} 2 \mathrm{X}$ receptor subtypes [33]. P2X7 receptor mRNA was also detected to a small extent. They also showed expression of mRNAs for P2Y1, P2Y2, P2Y6, P2Y11, and P2Y12 receptors. Slight expression of $\mathrm{P} 2 \mathrm{Y} 4$ receptor was also detected. The expression patterns of multiple $\mathrm{P} 2 \mathrm{Y}$ and $\mathrm{P} 2 \mathrm{X}$ receptor in normal human keratinocytes were also analyzed by Inoue et al. [34]. They confirmed the expression of P2X1, P2X4, P2X5, $\mathrm{P} 2 \mathrm{X} 6, \mathrm{P} 2 \mathrm{X} 7, \mathrm{P} 2 \mathrm{Y} 1, \mathrm{P} 2 \mathrm{Y} 2, \mathrm{P} 2 \mathrm{Y} 4, \mathrm{P} 2 \mathrm{Y} 11, \mathrm{P} 2 \mathrm{Y} 12$, and $\mathrm{P} 2 \mathrm{Y} 13$ receptors. Although the expression levels of P2 receptors varied in all samples, P2Y1, P2Y11, and P2X5 receptor subtypes were consistently expressed. The expression of $\mathrm{P} 2 \mathrm{Y} 2$ was detected in three of four strains. The expression of $\mathrm{P} 2 \mathrm{Y} 12$ was detected in one of four strains. P2Y13 was detected in two of four strains. The expression of $\mathrm{P} 2 \mathrm{X} 1$ and $\mathrm{P} 2 \mathrm{X} 4$ was detected in three of four strains. The expression of $\mathrm{P} 2 \mathrm{X} 7$ was detected in two of four strains and the expression of P2X6 was detected in one strain.
Apart from keratinocytes which are the largest population of epidermal cells in the skin (up to 95\%), melanocytes, Langerhans' cells and Markel cells are present within the epidermis. Langerhans cells (LCs) are an important subclass of dendritic cells that reside in the epidermis. Monocyte-derived dendritic cells have been shown to express P2X1, P2X4, P2X7, P2Y1, P2Y2, P2Y5, and $\mathrm{P} 2 \mathrm{Y} 11$ receptors [35]. LC-like cell line has been found to express mRNA for P2X1, P2X7, P2Y1, P2Y2, P2Y4, $\mathrm{P} 2 \mathrm{Y} 9$, and P2Y11 receptors [36]. Georgiou et al. have demonstrated that functional $\mathrm{P} 2 \mathrm{X} 7$ is present on human epidermal LCs and monocyte-derived LCs [37].

While P2Y1, P2Y2, P2Y6, and P2X7 have been described in the human melanoma cell lines and tissues $[38,39]$, relatively little is known about the expression in melanocytes. Deli et al. have observed some faint nuclear P2X7 immunopositivity in primary human melanocyte cultures melanocytes; however, they have shown no response to ATP [40].

Fibroblasts are considered to be the major cell type of the dermis and they participate in a complex process of tissue repair. Cutaneous tissue damage induces a proinflammatory reaction resulting in the activation of fibroblasts which repopulate the damaged area during the granulation phase of tissue repair. Tissue fibroblasts represent the main source of cells for promoting the reconstruction of the connective tissue in the wound. In human dermal fibroblasts, reverse transcription polymerase chain reaction (RT-PCR) amplification has revealed expression of P2X3, $\mathrm{P} 2 \mathrm{X} 4, \mathrm{P} 2 \mathrm{X} 7, \mathrm{P} 2 \mathrm{Y} 1, \mathrm{P} 2 \mathrm{Y} 2, \mathrm{P} 2 \mathrm{Y} 4$, and P2Y6 receptors [41]. Solini et al. have also provided evidence for existence functional P2X7 receptor in these cells [42]. Among P2 receptor subclasses expressed in human fibroblasts isolated from skin biopsies, P2Y6 and P2X7 mRNA are not detected in subepithelial fibroblasts of rat small intestinal villi. In the latter cells, $\mathrm{P} 2 \mathrm{Y} 1$ and $\mathrm{P} 2 \mathrm{Y} 4 \mathrm{mRNA}$ are dominantly expressed and $\mathrm{P} 2 \mathrm{Y} 2$ and $\mathrm{P} 2 \mathrm{X} 1$ have minor intensity [43].

During normal wound healing, fibroblasts migrate to the wound area and differentiate into myofibroblasts under the influence of growth factors such as transforming growth factor $\beta 1$ (TGF- $\beta 1)$ and the mechanical stress developed within a given tissue [reviewed in 44]. Myofibroblasts are an unique group of cells phenotypically intermediate between smooth muscle cells and fibroblasts. They are characterized by the presence of stress fibers containing the $\alpha$-actin isoform that is expressed in smooth muscle cells and they disappear with the completion of healing. Little information is available about expression of nucleotide receptors on human dermal myofibroblats. Rat cardiac myofibroblasts express six P2Y receptor subtypes (P2Y1, $2,4,6,11,13)$, however only five (P2Y1, 2, 4, 6, 11) have been functionally detected [45]. Guinea pig suburothelial 
myofibroblasts are strongly labeled with the P2Y6 antibody. There is weaker staining for $\mathrm{P} 2 \mathrm{X} 3, \mathrm{P} 2 \mathrm{Y} 2$, and $\mathrm{P} 2 \mathrm{Y} 4$, but none to P2Y1 [46]. Expression of P2X3 purinoceptors in suburothelial myofibroblasts of the normal human urinary bladder has been confirmed by Liu et al. [47]. Liang et al. have reported that $\mathrm{P} 2 \mathrm{Y} 2$ receptor stimulation by ATP and UTP induces endoplasmic reticulum $\mathrm{Ca}^{2+}$ release and $\mathrm{Ca}^{2+}$ influx in human valvular myofibroblasts [48]. Since myofibroblasts are ubiquitous cells with similar properties and functions that have similar morphological characteristics and function regardless of their tissue location, one may presume that at least $\mathrm{P} 2 \mathrm{X} 3$ and $\mathrm{P} 2 \mathrm{Y} 2$ receptors are present on human dermal myofibroblats.

Mast cells also play a fundamental role in remodeling and repair process by protecting against bacterial infection and maintain tissue homeostasis. Human mast cells from different sources express different pattern of nucleotide receptors due to their heterogeneity. For example, mast cells isolated from lung and skin do not express $\mathrm{P} 2 \mathrm{X} 7$ while this receptor is highly expressed by HMC-1 cell line and activated human cord blood mast cells (CBMCs). Mast cells isolated from human skin express $\mathrm{P} 2 \mathrm{X} 1$ and show only a marginal P2X4 receptor expression [49]. CBMCs express mRNA for P2X1 and P2X4 as well as for P2Y1, $\mathrm{P} 2 \mathrm{Y} 2$, P2Y11, P2Y12, and P2Y13 [50]. Expression pattern of $\mathrm{P} 2 \mathrm{Y}$ receptor subfamily in mast cells isolated from human skin has not been analyzed yet.

Endothelial cells, vascular smooth muscle cells, and fibroblasts are a key structural element of the blood vessel walls. Blood vessel regeneration is a vital component of normal wound healing. This process occurs through both angiogenesis (sprouting of capillaries from existing blood vessels) and vasculogenesis (mobilization of bone marrowderived endothelial stem cells). The most commonly used human endothelial cell for in vitro angiogenesis assays are human umbilical vein endothelial cells (HUVEC). Functional expression of P2X4 receptors, but not of P2X1, $\mathrm{P} 2 \mathrm{X} 2, \mathrm{P} 2 \mathrm{X} 3$, and $\mathrm{P} 2 \mathrm{X} 5$ receptors on HUVEC plasma membranes has been reported [51]. Northern blot analysis used in that study has demonstrated that P2X4 mRNA is expressed in HUVECs, human aortal endothelial cells (HAECs), human pulmonary artery endothelial cells (ECs), and human microvessel ECs. P2X1 is not expressed in any of EC lines studied. P2X4 is the most strongly expressed isoform in the HAECs and the P2X7 mRNA levels are $30 \%$ of the P2X 4 mRNA level. P2X3 and P2X5 expressions are $3 \%$ of the P2X 4 level. Similar P2X subtype mRNA expressions has been seen in HUVECs as well. These findings suggest that endothelial cells predominantly express P2X4 receptors among P2X receptor studied. Using confocal and electron microscopy, Glass et al. have demonstrated that P2X4 and P2X6 receptors show a similar expression pattern and they are closely colocalized with
VE-cadherin [52]. Using real-time PCR and Western blotting analysis, it has been also demonstrated that the $\mathrm{P} 2 \mathrm{X} 4, \mathrm{P} 2 \mathrm{Y} 11, \mathrm{P} 2 \mathrm{Y} 1$, and P2Y2 are the most expressed P2 receptors in HUVECs [53]. With regard to the fact that angiogenesis commonly involves the microvasculature rather than the macrovasculature, it should be taken into account differences between the lineage of these. Seiffert et al. have found strong expression of the P2X4, P2X5, P2X7, $\mathrm{P} 2 \mathrm{Y} 2$, and $\mathrm{P} 2 \mathrm{Y} 11$ receptors in transformed human microvascular endothelial cells, whereas expression of P2X1 and P2X3 has been faint [54].

Wang et al. have shown that P2X1, P2Y2, and P2Y6 receptors are the most expressed in human smooth muscle cells obtained from mammary artery [53]. RT-PCR analysis of endothelium-denuded human cerebral and omental arteries has demonstrated P2X1, P2Y1, P2Y2, and P2Y6 receptor mRNA expression. There has been no bands for the P2Y4 receptor mRNA in the omental arteries, while barely detectable in the cerebral arteries [55]. RT-PCR analysis of mRNA from endothelium-denuded human coronary arteries has demonstrated strong bands for P2Y2 and P2X1, although bands for P2Y1, P2Y4, and P2Y6 receptor mRNA could also be detected [56]. Similar results have been reported from rat arterial smooth muscle cells showing the P2Y2 receptor mRNA to be 10- and 100-fold more highly expressed than P2Y6 and P2Y4, respectively. The expression of the P2Y1 receptor was lower than that of the P2Y4 receptor [57].

All cell types involved in wound healing differentially express P2X and P2Y receptors, and the receptor expression patterns vary between cellular types. Moreover, differential expression of nucleotide receptor subtypes contributes to tissue cell heterogeneity which might be responsible for inducing a variety of responses by nucleotides present in the site of wounding.

\section{Extracellular nucleotides in hemostasis and inflammation}

Wound healing is a highly dynamic process involving interactions of extracellular matrix molecules, soluble mediators, and various cells that cooperate to repair formed injury. Wound repair is divided into four phases that overlap in time and space: hemostasis, inflammation, tissue formation (proliferative phase), and tissue remodeling (Fig. 1). All these phases exert specific contributions on blood vessel growth and remodeling [58].

Hemostasis and inflammation are first phases of tissue repair. Hemostasis is caused by leak of blood constituents and vasocative factors into the wound site. Platelets start to aggregate at the damaged site to form a fibrin clot which control active bleeding and facilitate invasion and migration 
of endothelial cells. Inflammatory phase is characterized by influx of polymorphonuclear leukocytes (neutrophils). Bacteria and debris are phagocytosed and then removed from the injury. In addition, inflammatory cells release angiogenic growth factors and proinflammatory cytokines, which control the recruitment of inflammatory and endothelial cells into the wound site. Immediately after injury, coagulation and hemostasis take place in the wound since platelet and coagulation factor-dependent thrombus formation is critical to limit posttraumatic blood loss at sites of vascular injury.

During the hemostasis phase of skin wound healing, extracellular nucleotides are abundant and play a crucial role in triggering thrombus formation. At the site of injury, activated platelets release ADP from their dense granules, which functions as a positive feedback mediator that binds to the receptors on the platelets' surface. Stimulation of the P2Y1 receptor mobilizes intracellular calcium and triggers a change in the platelet shape, aggregation, thromboxane A2 generation, procoagulant activity, adhesion to immobilized fibrinogen, and thrombus formation. ADP also activates P2Y12 receptor resulting in lowering of cyclic adenosine monophosphate level, amplification of the platelet response, stabilization of the resulting aggregates, and secretion of further mediators from the granules. The third P2X1 receptor present on platelets is an ATP-gated ion channel that upon activation causes an influx of calcium. The role of platelet P2X1 signaling is less well defined with respect to platelet activation and thrombus formation but it is known to cause shape change and support the activation process of other agonists [reviewed in 59].

Activated platelets trapped into the clot also release growth factors and proinflammatory cytokines which control the recruitment of inflammatory cells, endothelial cells, and fibroblasts into the wound site. ATP, ADP, and other nucleotides also act as a "danger-associated" molecular signal and affect various immunocompetent cells such as neutrophils, mast cells, dendritic cells, and dermal endothelial cells. Neutrophil recruitment to the site of inflammation is triggered by extracellular nucleotides. Verghese et al. have shown that ATP and UTP induce actin polymerisation and chemotaxis in human neutrophils via the activation of P2Y2 receptor [60]. Besides P2Y2, human neutrophils express $\mathrm{P} 2 \mathrm{X} 7, \mathrm{P} 2 \mathrm{Y} 4, \mathrm{P} 2 \mathrm{Y} 6$, and $\mathrm{P} 2 \mathrm{Y} 11$ receptor subtypes [61-63]. It has been found that human neutrophils release ATP from the leading edge of the cell surface to amplify chemotactic signals what helps neutrophils locate damaged tissues, which also generate extracellular ATP [20]. Chen et al. have recently shown that ATP is released from neutrophils through pannexin-1 hemichannels and P2Y2 purinergic signaling is a fundamental mechanism required for neutrophil activation and immune defense [64].
ATP has also chemotactic properties towards eosinophils and together with UDP induces secretion of interleukin (IL)- 8 by eosinophils. Activation of nucleotide receptors expressed on human macrophages induces secretion of IL-1 $\beta$, tumor necrosis factor (TNF)- $\alpha$, or IL- 18 [reviewed in 65]. Warny et al. demonstrated that UDP activates IL- 8 gene expression and IL-8 release in human monocytic cells [66].

ATP and UTP, probably via activation of the P2Y2, as well as ADP (via P2Y1) are thought to be potent chemotactic stimuli also for immature but not for mature DCs [67]. Besides direct chemotactic effects on DCs, extracellular nucleotides are also involved indirectly via their action on DCs in the trafficking of other leukocytes through the release of chemokines [reviewed in 65]. Also, immunity of mast cells is associated with extracellular nucleotides, e.g., the chemotaxis and degranulation are mediated by $\mathrm{P} 2 \mathrm{X} 7$ induced calcium release [reviewed in 68].

All immune and inflammatory cells express P2Y and $\mathrm{P} 2 \mathrm{X}$ receptors (Table 2), and their expression is modulated by inflammatory cytokines during development [69-73]. Among the P2 receptors, P2Y2, P2Y6, P2Y11, P2Y12, $\mathrm{P} 2 \mathrm{X} 4$, and $\mathrm{P} 2 \mathrm{X} 7$ are closely associated with immune responses. Special attention should be paid to the P2X7 subtype, as it is closely related to IL- $1 \beta$ and IL- 18 . IL- $1 \beta$ is a potent proinflammatory agent that can be driven by $\mathrm{P} 2 \mathrm{X} 7$ activation rather than by a passive process, as previously thought. It is possible that $\mathrm{P} 2 \mathrm{X} 7$ activation simultaneously opens the potassium channel and facilitates IL- $1 \beta$ secretion. Mice deficient in P2X7 exhibited markedly reduced inflammation, pain, and IL- $1 \beta$-mediated IL- 6 production [reviewed in 74].

Density of purinergic receptors may change during the course of inflammatory responses [reviewed in 75]. For example, the best characterized $\mathrm{P} 2 \mathrm{X} 7$ receptors on in monocytes and macrophages that are downregulated by anti-inflammatory cytokines (e.g., IL-4, IL-10) whereas they are upregulated by the proinflammatory mediators (e.g., TNF $\alpha, \operatorname{IFN} \gamma$, and lipopolysaccharide). With the upregulation of the $\mathrm{P} 2 \mathrm{X} 7$ receptors, inflammatory activation of monocytes induces downregulation of the $\mathrm{P} 2 \mathrm{Y} 2$ receptor $[76,77]$.

\section{Extracellular nucleotides in tissue formation}

Inflammatory mediators, released by macrophages and neutrophils, serve as chemotactic agents for invading fibroblasts and keratinocytes. The proliferative phase of wound healing is characterized by fibroblast migration, epithelialization, and wound contraction and deposition of newly synthesized extracellular matrix, acting as a replacement for the provisional network composed of fibrin and fibronectin. 
Table 1 Expression of P2 receptor subtypes on cells involved in wound healing

\begin{tabular}{|c|c|c|c|}
\hline Cell type & Receptor subtypes & Method of detection & References \\
\hline \multicolumn{4}{|l|}{ Keratinocytes } \\
\hline \multirow[t]{2}{*}{ NHK } & P2Y1, P2Y2, P2Y4, P2Y6 & RT-PCR & {$[12]$} \\
\hline & $\begin{array}{l}\mathrm{P} 2 \mathrm{X} 1, \mathrm{P} 2 \mathrm{X} 4, \mathrm{P} 2 \mathrm{X} 5, \mathrm{P} 2 \mathrm{X} 6, \mathrm{P} 2 \mathrm{X} 7, \mathrm{P} 2 \mathrm{Y} 1, \\
\mathrm{P} 2 \mathrm{Y} 2, \mathrm{P} 2 \mathrm{Y} 4, \mathrm{P} 2 \mathrm{Y} 11, \mathrm{P} 2 \mathrm{Y} 12 \text {, and } \mathrm{P} 2 \mathrm{Y} 13\end{array}$ & RT-PCR & [34] \\
\hline $\mathrm{HaCaT}$ & $\begin{array}{l}\mathrm{P} 2 \mathrm{X} 5, \mathrm{P} 2 \mathrm{X} 6, \mathrm{P} 2 \mathrm{Y} 1, \mathrm{P} 2 \mathrm{Y} 2, \mathrm{P} 2 \mathrm{Y} 6, \mathrm{P} 2 \mathrm{Y} 11, \\
\mathrm{P} 2 \mathrm{Y} 12>>\text { P2X7, P2Y4 }\end{array}$ & RT-PCR & {$[33]$} \\
\hline Dermal fibroblasts & $\begin{array}{l}\mathrm{P} 2 \mathrm{X} 4, \mathrm{P} 2 \mathrm{X} 7>\mathrm{P} 2 \mathrm{X} 3 \\
\mathrm{P} 2 \mathrm{Y} 1, \mathrm{P} 2 \mathrm{Y} 2, \mathrm{P} 2 \mathrm{Y} 4, \mathrm{P} 2 \mathrm{Y} 6\end{array}$ & RT-PCR & {$[41]$} \\
\hline Skin MC & $\mathrm{P} 2 \mathrm{X} 1>>\mathrm{P} 2 \mathrm{X} 4$ & GeneChip & [49] \\
\hline \multicolumn{4}{|l|}{ Endothelium } \\
\hline \multirow[t]{3}{*}{ HUVEC } & $\begin{array}{l}\mathrm{P} 2 \mathrm{X} 4>\mathrm{P} 2 \mathrm{Y} 11>\mathrm{P} 2 \mathrm{Y} 1>\mathrm{P} 2 \mathrm{Y} 2>> \\
\mathrm{P} 2 \mathrm{Y} 4, \mathrm{P} 2 \mathrm{Y} 6\end{array}$ & RT-qPCR and Wb & {$[53]$} \\
\hline & $\mathrm{P} 2 \mathrm{X} 4>>\mathrm{P} 2 \mathrm{X} 7>\mathrm{P} 2 \mathrm{Y} 1>\mathrm{P} 2 \mathrm{Y} 2$ & Competitive PCR analysis & {$[51]$} \\
\hline & $\mathrm{P} 2 \mathrm{X} 4=\mathrm{P} 2 \mathrm{X} 6$ & Confocal and electron microscopy & {$[52]$} \\
\hline HAECs & $\mathrm{P} 2 \mathrm{X} 4>>\mathrm{P} 2 \mathrm{X} 7>\mathrm{P} 2 \mathrm{Y} 1>\mathrm{P} 2 \mathrm{Y} 2$ & Competitive PCR analysis & {$[51]$} \\
\hline HPAEC & $\mathrm{P} 2 \mathrm{X} 4$ & $\mathrm{Nb}$ & {$[51]$} \\
\hline HMVEC & $\mathrm{P} 2 \mathrm{X} 4$ & $\mathrm{Nb}$ & {$[51]$} \\
\hline HMEC-1 & $\mathrm{P} 2 \mathrm{X} 4, \mathrm{P} 2 \mathrm{X} 5, \mathrm{P} 2 \mathrm{X} 7, \mathrm{P} 2 \mathrm{Y} 2, \mathrm{P} 2 \mathrm{Y} 11$ > P2X1 & RT-PCR & {$[54]$} \\
\hline VSMCs & $\mathrm{P} 2 \mathrm{X} 1>\mathrm{P} 2 \mathrm{Y} 2, \mathrm{P} 2 \mathrm{X} 4>\mathrm{P} 2 \mathrm{Y} 6>\mathrm{P} 2 \mathrm{Y} 1, \mathrm{P} 2 \mathrm{Y} 4$ & RT-qPCR and $\mathrm{Wb}$ & {$[51]$} \\
\hline Endothelium-denuded cerebral arteries & $\mathrm{P} 2 \mathrm{X} 1>\mathrm{P} 2 \mathrm{Y} 2>\mathrm{P} 2 \mathrm{Y} 6>\mathrm{P} 2 \mathrm{Y} 1>>\mathrm{P} 2 \mathrm{Y} 4$ & RT-PCR & {$[55]$} \\
\hline Endothelium-denuded omental arteries & $\mathrm{P} 2 \mathrm{X} 1>\mathrm{P} 2 \mathrm{Y} 1, \mathrm{P} 2 \mathrm{Y} 2, \mathrm{P} 2 \mathrm{Y} 6$ & RT-PCR & {$[55]$} \\
\hline
\end{tabular}

$W b$ Western blot, $N b$ Northern blot, $M C$ mast cells, $q P C R$ quantitative PCR, RT-PCR reverse transcription PCR, HPAECs human pulmonary artery ECs, HMVEC human microvessel endothelial cell, HMEC-1 transformed human microvascular endothelial cell line one

Following injury, fibroblasts and myofibroblasts in the surrounding tissue are activated to proliferate and migrate into the wound. In the wound, they proliferate profusely and produce the extracellular matrix proteins. Both, fibroblasts and myofibroblasts play a crucial role in wound healing by generating traction and contractile forces-to enhance wound contraction. Myofibroblasts become the most abundant in the proliferation phase of wound healing and progressively disappear in the later stage of healing. Fibroblasts are well-known not only for being the major producers of extracellular matrix, but also a cell type actively involved in synthesis of inflammatory mediators

Table 2 Immune cell distribution of nucleotide receptor subtypes

\begin{tabular}{llc}
\hline Subtype & Immune cell distribution & References \\
\hline P2X1 & Neutrophils, eosinophils, lymphocytes, lymphocytes, monocytes, dendritic cells & {$[65,67,70-72]$} \\
P2X2 & Lymphocytes & {$[65,71]$} \\
P2X3 & & {$[65,67,69,72]$} \\
P2X4 & Eosinophils, lymphocytes, monocytes, dendritic cells & {$[65,72]$} \\
P2X5 & Dendritic cells & {$[63,67,69-72]$} \\
P2X6 & & {$[65,69,70,72]$} \\
P2X7 & Eosinophils, B lymphocytes, T lymphocytes, monocytes, macrophages, dendritic cells & {$[65,67,69,70,72]$} \\
P2Y1 & Neutrophils, eosinophils, lymphocytes, monocytes, dendritic cells & {$[65,67,69,70,72]$} \\
P2Y2 & Neutrophils, eosinophils, polymorphonuclear neutrophils, lymphocytes, monocytes, macrophages, dendritic cells & {$[65,69,70,72]$} \\
P2Y4 & Neutrophils, eosinophils, lymphocytes, monocytes, macrophages, dendritic cells & {$[65,67,69,70,72]$} \\
P2Y6 & Neutrophils, eosinophils, lymphocytes, monocytes, macrophages, dendritic cells & {$[65,69]$} \\
P2Y11 & Neutrophils, eosinophils, lymphocytes, monocytes, dendritic cells & {$[65,69]$} \\
P2Y12 & Monocytes, lymphocytes, dendritic cells & {$[65,73]$} \\
P2Y13 & Monocytes, lymphocytes, & \\
P2Y14 & Eosinophils, dendritic cells & \\
\hline
\end{tabular}


and tissue repair. Primary fibroblasts react to stimulation with ATP with striking morphological alterations and an increased formation of cytoplasmic microvesicles. In addition, fibroblast $\mathrm{P} 2 \mathrm{X} 7$ receptor triggers IL-6 release [42]. IL-6 is one of the most important proinflammatory cytokines, secreted from mononuclear phagocytes and antigen-presenting cells as well as fibroblasts. Janssen et al. have demonstrated that ATP acting on human pulmonary fibroblasts via P2Y receptors (likely P2Y4, P2Y6, and/or $\mathrm{P} 2 \mathrm{Y} 11$ subtypes) induces increased gene expression of P2Y4 receptors and TGF- $\beta$ (an important modulator of wound repair) [78]. Others have shown ATP to induce a mitogenic response in human fibroblasts [79].

In parallel to the formation of granulation tissue, increased proliferation and migration of keratinocytes takes place. During reepithelialization, basal keratinocytes undergo morphological changes required for their migration from the wound margin over the denuded area [80]. Greig et al. have reported that adult human epidermis express P2X5, P2X7, $\mathrm{P} 2 \mathrm{Y} 1$, and $\mathrm{P} 2 \mathrm{Y} 2$ receptors, each of which is expressed in a spatially distinct zone of the epidermis and has distinct cellular functions [32]. $\mathrm{P} 2 \mathrm{Y} 1$ and $\mathrm{P} 2 \mathrm{Y} 2$ receptors are involved in basal keratinocyte proliferation. P2X5 receptors are found in proliferating and differentiating keratinocytes in epidermis but they are likely to be more involved in keratinocyte differentiation. As P2X7 receptors are strongly linked to apoptosis $\mathrm{P} 2 \mathrm{X} 7$ receptors are likely to be part of the machinery of end-stage terminal differentiation/apoptosis of keratinocytes in the stratum corneum. Thus, the turnover of keratinocytes in the squamous epithelium of the epidermis is strictly connected with differential distribution of nucleotide receptors. Also, purinergic receptor expression is modulated in regenerating epidermis, which suggests that these receptors may have important functions during wound healing. Reepithelization is the resurfacing of a wound with new epithelium and consists of both migration and proliferation of keratinocytes at the periphery of the wound. After injury, keratinocytes become activated and change to a migratory phenotype. As epidermal migration moves on, keratinocytes at the wound margin begin to proliferate behind the actively migrating cells. The resulting dense hyperproliferative epithelium feeds the migrating sheets at the wound margins [81]. Greig et al. have shown that P2X5, P2X7, P2Y1, and $\mathrm{P} 2 \mathrm{Y} 2$ receptor expression in the epidermis is altered during wound healing. P2Y1 receptor expression is significantly increased in keratinocytes of the regenerating epidermis of the denervated wounds but $\mathrm{P} 2 \mathrm{Y} 2$ receptor expression is significantly decreased. The expression of P2X5 receptors in keratinocytes is significantly increased during wound healings in suprabasal as well as basal keratinocytes. This could represent part of the change of phenotype that keratinocytes undergo in order to become migratory during the wound healing process [82].
In vitro studies have revealed that in primary normal human keratinocytes and in the HaCaT keratinocyte cell line P2Y2 receptor is the predominant functional receptor that mediates several biological responses induced by ATP and UTP, such as cell proliferation and IL- 6 production $[14,33]$. Taboubi et al. have demonstrated that activation of P2Y2 by ATP and UTP is also connected with inhibition of keratinocyte spreading and lamellipodium dynamics, and disorganization of the actin cytoskeleton and focal contacts [83]. Recent data has indicated that in keratinocytes, P2Y2 signaling inhibits insulin-like growth factor-I (IGF-I)-induced p110 $\alpha$ - phosphoinositol 3-kinase (PI3K) activity in a $\mathrm{G}(\mathrm{q} / 11)$-dependent manner [84]. IGF-I activation of PI3K is an essential pathway for migration that is required for epidermis wound healing. It has been also shown that extracellular UTP delays IGF-I-induced PI3K-mediated keratinocyte migration by inhibiting both cell spreading and cell velocity. During skin wound healing, extracellular nucleotides may have a dual function, i.e., inhibiting keratinocyte motility and facilitating migration of other cell types (e.g., endothelial cells) $[83,85]$ or vascular smooth muscle cells [86]. Besides antimotogenic properties, purines and pyrimidines are involved in the proliferation of keratinocytes acting synergistically with growth factors shown to stimulate the process of wound healing (e.g., PDGF, TGF alpha, and EGF) [87]. Resulting nucleotide-enhanced proliferation of cells in the basal layer may promote healing of an epidermal wound by replacing damaged epidermis.

The proliferative phase of wound healing is also characterized by fibroblast migration and deposition of newly synthesized extracellular matrix. Once in the wound, they proliferate and produce the matrix proteins: hyaluronan, fibronectin, proteoglycans, and type 1 and 3 procollagen. Collagens are an important component in all phases of wound healing. Synthesized by fibroblasts, they impart integrity and strength to all tissues and play a key role, especially in the proliferative and remodeling phases of repair. Janssen et al. have reported that in cultured human pulmonary fibroblasts, ATP increases gene expression two matrix proteins (collagen A1 and fibronectin) approximately four to five times above baseline [78]. Stimulation of ECM gene expression by extracellular nucleotides has been also confirmed in other cell systems. Recently, Waldman et al. have demonstrated that supplementation with ATP has a profound effect on the growth and maturation of the developed tissue [88]. Exogenous ATP has increased biosynthesis of collagen and proteoglycans in isolated bovine articular chondrocytes.

\section{Extracellular nucleotides in formation of new blood vessels}

Angiogenesis, the growth of new blood vessels is critical in wound healing and takes place during all phases of the 
reparative process. Since angiogenesis is a multistep process, it has to be under a complex control system with proangiogenic and antiangiogenic factors. One of the most important proangiogenic factors is vascular endothelial growth factor (VEGF). Extracellular purine and pyrimidine nucleotides also have been shown to have many hallmarks of proangiogenic factors. Stimulation of endothelial and smooth muscle proliferation and migration by nucleotides is an important component of establishment of new blood vessels. Endothelial cells derived from large and small vessels express several types of purinergic receptors (Table 1). ATP-, ADP-, UTP-, and UDPinduced stimulation of $\mathrm{P} 2 \mathrm{Y}$ receptors results in a mitogenic effect on rat brain capillary endothelial cells [89], bovine corneal endothelial cells [90], and guinea pig cardiac endothelial cells [91]. UTP is angiogenic in the chorioallantoic membrane of the chicken embryos [91]. Also nonhydrolysable nucleotide analogs commonly used in pharmacological studies (e.g., ATP $\gamma \mathrm{S}, \mathrm{ADP} \beta \mathrm{S}$ ) have strong proliferative effect on HUVEC cells [92]. The mitogenic effects of extracellular nucleotides have been demonstrated in rat, porcine, bovine VSMC, and cells from human coronary arteries, aorta, and subcutaneous arteries and veins [93]. Stimulation of porcine coronary smooth muscle cells with UTP and ATP induces increase in cellular DNA content, protein synthesis, cell number, and proliferating cell nuclear antigen expression, indicating a mitogenic role for $\mathrm{P} 2 \mathrm{Y} 2$ receptors [94]. It also has been shown that stimulation of the P2Y2 receptor by ATP or UTP in smooth muscle cells and human umbilical vein ECs leads to cell migration $[57,85]$.

Characterization of the signaling pathways contributing to angiogenesis stimulated by extracellular nucleotides is important in developing pharmacologic strategies for both pro- and anti-angiogenic therapy. It has been reported that ERK1/2 and PI3K pathways play a critical role in extracellular ATPinduced proliferation of vascular smooth muscle cells [95]. In human coronary artery endothelial cells, activated P2Y2 receptors can transactivate vascular endothelial growth factor receptor-2 (VEGFR-2), suggesting a direct link between extracellular nucleotides and angiogenesis signaling [96]. Rumjahn et al. have demonstrated that P2Y1 stimulation of human endothelial cells activates VEGFR-2 intracellular signaling to stimulate endothelial cell tubulogenesis, a direct in vitro measure of angiogenesis [97]. In VSMCs extracellular nucleotides also promote actin cytoskeletal reorganization in a P2Y2 and Rho kinase-dependent manner [86]. Recently, it has been demonstrated that P2X7 activation promotes the robust release of vascular endothelial growth factor from primary human monocytes [98]. This new action of $\mathrm{P} 2 \mathrm{X} 7$ receptor suggests that it may not only participate in inflammation and cell death but that it is also likely to be important in the control of angiogenesis and wound repair.

Another link between purinergic signaling and angiogenesis signaling concerns integrins. P2Y2 receptor con- tains the consensus integrin-binding domain arginineglycine-aspartic acid in its first extracellular loop that binds selectively to $\alpha_{v} \beta_{3} / \beta_{5}$ integrins [99]. P2Y2 colocalization with $\alpha_{v} \beta_{3}$ integrin enables nucleotides to activate integrinassociated responses such as cytoskeletal rearrangements that control cell migration. In human endothelial cells, ATP and UTP stimulates phosphorylation of several proteins that are associated with integrin signaling and involved in focal adhesion: focal adhesion kinase (FAK), paxillin, and p130 Crk-associated substrate (p130 ${ }^{\text {cas }}$ ), leading to EC spreading and migration [85].

Angiogenesis occurring during various pathological conditions (e.g., tissue damage) is connected with hypoxic conditions. Hypoxia has been shown to stimulate release of ATP from both cells of the vascular wall as well as circulating blood cells. Studies on human HUVEC and bovine aortic EC have demonstrated that hypotonic stress-induced ATP release is mediated by a mechanism that involves actin cytoskeleton reorganization and activation of Rho/ROCK and FAK/paxillin pathways [100, 101]. Hypoxia also results in time- and $\mathrm{O}_{2}$-dependent ATP release from pulmonary artery adventitial vasa vasorum endothelial cells (VVEC) [102]. It has been shown that extracellular ATP and ADP exert angiogenic effects on isolated VVECs characterized by expansion under hypoxic conditions [103]. In VVECs, ATP augments the effects of other angiogenic factors (VEGF and basic FGF) known to be present in the hypoxic microenvironment and $\mathrm{PI} 3 \mathrm{~K} / \mathrm{Akt} / \mathrm{mTOR}$ and ERK $1 / 2$ play a critical role in mediating the extracellular ATP-induced mitogenic and migratory responses. It has been also demonstrated that P2Y1 and P2Y13 receptors play a major role in VVEC growth responses [104].

It should be taken into consideration that once released, ATP is rapidly hydrolyzed to ADP, AMP, and finally, adenosine. A product of extracellular ATP hydrolysis, adenosine, has been also shown to be angiogenic for both microvascular and macrovascular endothelial cells [reviewed in 105]. However, Gerasimovskaya et al. have demonstrated that hypoxia not only induces release of ATP into the extracellular milieu from fibroblasts and endothelial cells but also delayed ATP hydrolysis [28]. Acute hypoxia induces significant increases in extracellular ATP, supporting the possibility of autocrine-induced changes in purinoceptor activation and subsequent cell signaling.

\section{Extracellular nucleotides in remodeling}

Metalloproteinases and their inhibitors are involved in the control of all aspects of wound healing. Metalloproteinase cleavage of signaling molecules and ECM proteins occurs during the inflammatory phase, where MMPs, especially MMP-1, -3, -7, and -9, are capable of regulating chemokine 
activity. ATP-stimulated P2X7 receptor has been shown to play a role in rapid release of MMP-9 from monocytes, which is required in the early phase of the inflammatory response [106]. Degradation of cell adhesion molecules as well as ECM proteins by MMPs is also necessary during the repair phase, where MMP-1, 7-, -9, and -10 are required for cell migration. Finally, during the remodeling phase of wound healing, MMP-1, -3 and -13 as well as MMP-14 are capable of cleaving collagen, and MMP-7 can process elastin [107]. The remodeling of the newly formed granulation tissue is responsible for the development of new epithelium and final scar tissue formation. Waldman et al. have recently demonstrated that ATP stimulates expression of MMP-13 (also known as collagenase-3) in cultures of isolated bovine articular chondrocytes [88]. ATP has been also shown to promote expression of MMP-3 and MMP-13 in prostate cancer cells [108].

The remodeling process is dependent not only on the coordinated activity of members of the matrix metalloproteinase family but also on components of the plasminogen activation system, which converts the inactive plasminogen to the serine protease plasmin. Plasmin cleaves fibrin, dissolves the fibrin-containing clot which may cause occlusion of the vessel or block cell migration during tissue healing. Plasmin also digests ECM proteins, including laminin and fibronectin as well it activates several MMPs, including MMP-1, -13, -9, -3, -7 [109]. ATP and UTP can induce tissue plasminogen activator release from the vascular endothelium in vivo in man at submicromolar concentrations [110]. On the other hand, uridine nucleotides are highly potent stimulators of plasminogen activator inhibitor-1 (PAI-1) expression and ATP or ADP suppress PAI-1 expression in rat vascular smooth muscle cells [111] suggesting a delicate balance in activation of the endogenous fibrinolytic system by nucleotides.

\section{The role of $\mathrm{P} 2$ receptors in the in the corneal wound healing}

Whereas our knowledge concerning the injury-induced cellular responses elicited by extracellular nucleotides in vitro is increasing at a rapid pace, very little is known about their effect in vivo. The cornea is an excellent tissue to study the response to injury because corneal epithelial cells are superficial, avascular, and devoid of direct lymphatic supply. P2Y1, P2Y2, P2Y4, P2Y6, and P2Y11 receptors have been found in corneal epithelial cells and inhibition of these receptors attenuated epithelial wound healing in vitro [112]. Additionally, the presence of nucleotides in tears may suggest a role in the healing process [113].

Studies of Pintor et al. have revealed that the application of UTP increases the rate of healing in New Zealand white rabbits whose corneas were injured with n-heptanol [114]. Weinger et al. have demonstrated that after injury of corneal epithelial cells intracellular $\mathrm{Ca}^{2+}$ wave propagating from the site of injury to neighboring cells is mediated by the release of extracellular nucleotides activating P2Y2 and P2Y4 receptors [115]. It has been suggested that the activation of P2Y2 receptors accelerates the rate of corneal epithelial cell migration while the stimulation of a P2Y6 does the opposite [116]. Yin et al. have additionally demonstrated that the release of endogenous ATP upon mechanical injury serves as one of the extracellular mediators that trigger EGFR transactivation and the activation of its downstream signaling pathways in corneal epithelial cells [11]. Recent in vivo studies indicate that the $\mathrm{P} 2 \mathrm{X} 7$ receptor also plays a fundamental role in the corneal epithelium and stroma. Through the use of P2X7 knockout mice, Mayo et al. have shown that $\mathrm{P} 2 \mathrm{X} 7$ is necessary for timely healing of abrasion wounds and normal stromal collagen structure [117].

These findings and understanding pnenomena underlying the response to injury in cornea may establish a prototype for injury in other tissues. There are very few reports of the use of extracellular nucleotides for the enhancement of non-corneal wound healing. The efficacy of UTP has been tested in an in vivo model of dexamethasone-impaired wound healing in mice [10]. Topical treatment with a gel formulation of UTP improves healing, which reaches the rate of normal, undisturbed wounds. The in vivo studies on purinergic substances confirm possibilities of development of new nucleotide drugs in pharmacological wound care.

\section{Conclusions}

There is increasing interest in the therapeutic potential of compounds that act through purinergic receptors for treating a wide range of diseases. The $\mathrm{P} 2 \mathrm{Y} 2$ receptor agonists diuridine tetraphosphate (diquafosol) and the uracil cytosine dinucleotide (denufosol) are currently undergoing clinical trials for dry eye disease, retinal detachment disease, upper respiratory tract symptoms, and cystic fibrosis [118]. Thienopyridine clopidogrel is the most widely used blocker of ADP-induced platelet aggregation [119]. It is clear that selective and stable nucleotide compounds may also lead to applications P2 receptors' agonists/antagonists in treating wound healingrelated diseases. Researches of the last decade have demonstrated that also enzymes of nucleotide metabolism could be novel targets for therapeutic intervention of wound healing if we take into consideration the presence of enzymes cleaving nucleotides. A detailed description of the enzymatic reactions contributing to the pathways of extracellular nucleotides' degradation is beyond the scope of this review but can be found in a number of recent reviews [e.g., 
120]. After release into the extracellular space, ATP is rapidly hydrolyzed by ecto-nucleotidases to pharmacologically active adenosine promoting wound healing itself [reviewed in 105].

While much has recently been learned about the involvement of extracellular nucleotides in wound healing, many problems remain to be solved. We have to take into consideration that nucleotide and adenosine receptors as well as multiple ecto-nucleotidases are coexpressed in the same cells and a mixture of extracellular nucleotides is released by different kinds of cells. However, expanding our understanding of a local purinergic signaling network in wound healing maybe then translated to clinical benefit to use nucleotides or their analogs for treatments of wound healing disorders.

Acknowledgments This work was supported by a grant $(\mathrm{N}-405$ 3047 36) from the Ministry of Science and Higher Education.

Open Access This article is distributed under the terms of the Creative Commons Attribution Noncommercial License which permits any noncommercial use, distribution, and reproduction in any medium, provided the original author(s) and source are credited.

\section{References}

1. Burnstock G (2007) Purine and pyrimidine receptors. Cell Mol Life Sci 64:1471-1483

2. Browne LE, Jiang LH, North RA (2010) New structure enlivens interest in P2X receptors. Trends Pharmacol Sci 31:229-237

3. Kennedy C, Qi AD, Herold CL, Harden TK, Nicholas RA (2000) ATP, an agonist at the rat $\mathrm{P} 2 \mathrm{Y}(4)$ receptor, is an antagonist at the human P2Y(4) receptor. Mol Pharmacol 57:926-931

4. Communi D, Govaerts C, Parmentier M, Boeynaems JM (1997) Cloning of a human purinergic $\mathrm{P} 2 \mathrm{Y}$ receptor coupled to phospholipase $\mathrm{C}$ and adenylyl cyclase. J Biol Chem 272:31969-31973

5. Hollopeter G, Jantzen HM, Vincent D, Li G, England L, Ramakrishnan V, Yang RB, Nurden P, Nurden A, Julius D, Conley PB (2001) Identification of the platelet ADP receptor targeted by antithrombotic drugs. Nature 409:202-207

6. Communi D, Gonzalez NS, Detheux M, Brezillon S, Lannoy V, Parmentier M, Boeynaems JM (2001) Identification of a novel human ADP receptor coupled to $\mathrm{G}_{\mathrm{i}}$. J Biol Chem 276:41479-41485

7. Abbracchio MP, Boeynaems JM, Barnard EA, Boyer JL, Kennedy C, Miras-Portugal MT, King BF, Gachet C, Jacobson KA, Weisman GA, Burnstock G (2003) Characterization of the UDP-glucose receptor (re-named here the P2Y14 receptor) adds diversity to the P2Y receptor family. Trends Pharmacol Sci 24:52-55

8. von Kügelgen I (2006) Pharmacological profiles of cloned mammalian P2Y-receptor subtypes. Pharmacol Ther 110:415-432

9. Abbracchio MP, Burnstock G, Boeynaems JM, Barnard EA, Boyer JL, Kennedy C, Knight GE, Fumagalli M, Gachet C, Jacobson KA, Weisman GA (2006) International Union of Pharmacology LVIII: update on the P2Y G protein-coupled nucleotide receptors: from molecular mechanisms and pathophysiology to therapy. Pharmacol Rev 58:281-341

10. Braun M, Lelieur K, Kietzmann M (2006) Purinergic substances promote murine keratinocyte proliferation and enhance impaired wound healing in mice. Wound Repair Regen 14:152-161
11. Yin J, Xu K, Zhang J, Kumar A, Yu FS (2007) Wound-induced ATP release and EGF receptor activation in epithelial cells. J Cell Sci 120:815-825

12. Schwiebert EM, Zsembery A (2003) Extracellular ATP as a signaling molecule for epithelial cells. Biochim Biophys Acta 1615:7-32

13. Dixon CJ, Bowler WB, Littlewood-Evans A, Dillon JP, Bilbe G, Sharpe GR, Gallagher JA (1999) Regulation of epidermal homeostasis through $\mathrm{P}_{2} \mathrm{Y}_{2}$ receptors. $\mathrm{Br} \mathrm{J}$ Pharmacol 127:1680-1686

14. Burrell HE, Bowler WB, Gallagher JA, Sharpe GR (2003) Human keratinocytes express multiple P2Y-receptors: evidence for functional P2Y1, P2Y2, and P2Y4 receptors. J Invest Dermatol 120:440-447

15. Mizumoto N, Mummert ME, Shalhevet D, Takashima A (2003) Keratinocyte ATP release assay for testing skin-irritating potentials of structurally diverse chemicals. J Invest Dermatol 121:1066-1072

16. Kahner BN, Shankar H, Murugappan S, Prasad GL, Kunapuli SP (2006) Nucleotide receptor signaling in platelets. J Thromb Haemost 4:2317-2326

17. Gordon JL (1986) Extracellular ATP: effects, sources and fate. Biochem J 233:309-319

18. Dubyak GR, El-Moatassim C (1993) Signal transduction via P2-purinergic receptors for extracellular ATP and other nucleotides. Am J Physiol 265:C577-C606

19. Zigmond SH (1977) Ability of polymorphonuclear leukocytes to orient in gradients of chemotactic factors. J Cell Biol 75:606616

20. Chen Y, Corriden R, Inoue Y, Yip L, Hashiguchi N, Zinkernagel A, Nizet V, Insel PA, Junger WG (2006) ATP release guides neutrophil chemotaxis via $\mathrm{P} 2 \mathrm{Y} 2$ and $\mathrm{A} 3$ receptors. Science 314:1792-1795

21. Sprague RS, Ellsworth ML, Stephenson AH, Lonigro AJ (1996) ATP: the red blood cell link to NO and local control of the pulmonary circulation. Am J Physiol 271:H2717-H2722

22. Bergfeld GR, Forrester T (1992) Release of ATP from human erythrocytes in response to a brief period of hypoxia and hypercapnia. Cardiovasc Res 26:40-47

23. Yegutkin G, Bodin P, Burnstock G (2000) Effect of shear stress on the release of soluble ecto-enzymes ATPase and 5'-nucleotidase along with endogenous ATP from vascular endothelial cells. Br J Pharmacol 129:921-926

24. Grierson JP, Meldolesi J (1995) Shear stress-induced [Ca2+]i transients and oscillations in mouse fibroblasts are mediated by endogenously released ATP. J Biol Chem 270:4451-4456

25. Bodin P, Bailey D, Burnstock G (1991) Increased flow-induced ATP release from isolated vascular endothelial cells but not smooth muscle cells. Br J Pharmacol 103:1203-1205

26. Prosdocimo DA, Douglas DC, Romani AM, O'Neill WC, Dubyak GR (2009) Autocrine ATP release coupled to extracellular pyrophosphate accumulation in vascular smooth muscle cells. Am J Physiol Cell Physiol 296:C828-C839

27. Bodin P, Burnstock G (1995) Synergistic effect of acute hypoxia on flow-induced release of ATP from cultured endothelial cells. Experientia 51:256-259

28. Gerasimovskaya EV, Ahmad S, White CW, Jones PL, Carpenter TC, Stenmark KR (2002) Extracellular ATP is an autocrine/paracrine regulator of hypoxia-induced adventitial fibroblast growth. Signaling through extracellular signal-regulated kinase-1/2 and the Egr-1 transcription factor. J Biol Chem 277:44638-44650

29. Bozzo J, Hernandez MR, Galan AM, Heras M, Ordinas A, Escolar G (1999) Impaired antiplatelet effects of aspirin associated with hypoxia and ATP release from erythrocytes. Studies in a system with flowing human blood. Eur J Clin Investig 29:438-444 
30. Lazarowski ER, Boucher RC (2001) UTP as an extracellular signaling molecule. News Physiol Sci 16:1-5

31. Lazarowski ER, Boucher RC, Harden TK (2003) Mechanisms of release of nucleotides and integration of their action as $\mathrm{P} 2 \mathrm{X}$ - and P2Y-receptor activating molecules. Mol Pharmacol 64:785-795

32. Greig AV, Linge C, Terenghi G, McGrouther DA, Burnstock G (2003) Purinergic receptors are part of a functional signaling system for proliferation and differentiation of human epidermal keratinocytes. J Invest Dermatol 120:1007-1015

33. Yoshida H, Kobayashi D, Ohkubo S, Nakahata N (2006) ATP stimulates interleukin-6 production via $\mathrm{P} 2 \mathrm{Y}$ receptors in human HaCaT keratinocytes. Eur J Pharmacol 540:1-9

34. Inoue K, Hosoi J, Denda M (2007) Extracellular ATP has stimulatory effects on the expression and release of IL-6 via purinergic receptors in normal human epidermal keratinocytes. J Invest Dermatol 127:362-371

35. Ferrari D, La Sala A, Chiozzi P, Morelli A, Falzoni S, Girolomoni G, Idzko M, Dichmann S, Norgauer J, Di Virgilio F (2000) The P2 purinergic receptors of human dendritic cells: identification and coupling to cytokine release. FASEB J $14: 2466-2476$

36. Granstein RD, Ding W, Huang J, Holzer A, Gallo RL, Di Nardo A, Wagner JA (2005) Augmentation of cutaneous immune responses by ATP gamma S: purinergic agonists define a novel class of immunologic adjuvants. J Immunol 174:7725-7731

37. Georgiou JG, Skarratt KK, Fuller SJ, Martin CJ, Christopherson RI, Wiley JS, Sluyter R (2005) Human epidermal and monocytederived Langerhans cells express functional P2X7 receptors. J Invest Dermatol 125:482-490

38. White N, Ryten M, Clayton E, Butler P, Burnstock G (2005) P2Y purinergic receptors regulate the growth of human melanomas. Cancer Lett 224:81-91

39. White N, Butler PE, Burnstock G (2005) Human melanomas express functional P2X(7) receptors. Cell Tissue Res 321:411418

40. Deli T, Varga N, Adam A, Kenessey I, Raso E, Puskas LG, Tovari J, Fodor J, Feher M, Szigeti GP, Csernoch L, Timar J (2007) Functional genomics of calcium channels in human melanoma cells. Int J Cancer 121:55-65

41. Solini A, Chiozzi P, Morelli A, Passaro A, Fellin R, Di Virgilio F (2003) Defective P2Y purinergic receptor function: A possible novel mechanism for impaired glucose transport. J Cell Physiol 197:435-444

42. Solini A, Chiozzi P, Morelli A, Fellin R, Di Virgilio F (1999) Human primary fibroblasts in vitro express a purinergic P2X7 receptor coupled to ion fluxes, microvesicle formation and IL-6 release. J Cell Sci 112:297-305

43. Furuya K, Sokabe M, Furuya S (2005) Characteristics of subepithelial fibroblasts as a mechano-sensor in the intestine: cell-shapedependent ATP release and P2Y1 signaling. J Cell Sci 118:3289-3304

44. Gabbiani G (2003) The myofibroblast in wound healing and fibrocontractive diseases. J Pathol 200:500-503

45. Talasila A, Germack R, Dickenson JM (2009) Characterization of $\mathrm{P} 2 \mathrm{Y}$ receptor subtypes functionally expressed on neonatal rat cardiac myofibroblasts. Br J Pharmacol 158:339-353

46. Sui GP, Wu C, Fry CH (2006) Characterization of the purinergic receptor subtype on guinea pig suburothelial myofibroblasts. BJU Int 97:1327-31

47. Liu F, Takahashi N, Yamaguchi O (2009) Expression of P2X3 purinoceptors in suburothelial myofibroblasts of the normal human urinary bladder. Int J Urol 16:570-575

48. Liang W, McDonald P, McManus B, van Breemen C, Wang X (2008) P2Y2 receptor-mediated $\mathrm{Ca} 2+$ signaling and spontaneous $\mathrm{Ca} 2+$ releases in human valvular myofibroblasts. Int Heart $\mathrm{J}$ 49:221-36
49. Bradding P, Okayama Y, Kambe N (2003) Ion channel gene expression in human lung, skin, and cord blood-derived mast cells. J Leukoc Biol 73:614-620

50. Feng C, Mery AG, Beller EM, Favot C, Boyce JA (2004) Adenine nucleotides inhibit cytokine generation by human mast cells through a $\mathrm{G}_{\mathrm{s}}$-coupled receptor. J Immunol 173:7539-7547

51. Yamamoto K, Korenaga R, Kamiya A, Qi Z, Sokabe M, Ando J (2000) P2X4 receptors mediate ATP-induced calcium influx in human vascular endothelial cells. Am J Physiol Heart Circ Physiol 279:H285-H292

52. Glass R, Loesch A, Bodin P, Burnstock G (2002) P2X4 and $\mathrm{P} 2 \mathrm{X} 6$ receptors associate with VE-cadherin in human endothelial cells. Cell Mol Life Sci 59:870-881

53. Wang L, Karlsson L, Moses S, Hultgardh-Nilsson A, Andersson M, Borna C, Gudbjartsson T, Jern S, Erlinge D (2002) P2 receptor expression profiles in human vascular smooth muscle and endothelial cells. J Cardiovasc Pharmacol 40:841-853

54. Seiffert K, Ding W, Wagner JA, Granstein RD (2006) ATPgammaS enhances the production of inflammatory mediators by a human dermal endothelial cell line via purinergic receptor signaling. J Invest Dermatol 126:1017-1027

55. Malmsjo M, Hou M, Pendergast W, Erlinge D, Edvinsson L (2003) Potent P2Y6 receptor mediated contractions in human cerebral arteries. BMC Pharmacol 3:4

56. Malmsjo M, Hou M, Harden TK, Pendergast W, Pantev E, Edvinsson L, Erlinge D (2000) Characterization of contractile P2 receptors in human coronary arteries by use of the stable pyrimidines uridine 5'-O-thiodiphosphate and uridine 5'-O-3thiotriphosphate. J Pharmacol Exp Ther 293:755-760

57. Pillois X, Chaulet H, Belloc I, Dupuch F, Desgranges C, Gadeau AP (2002) Receptors involved in UTP-induced rat arterial smooth muscle cell migration. Circ Res 90:678-681

58. Eming SA, Brachvogel B, Odorisio T, Koch M (2007) Regulation of angiogenesis: wound healing as a model. Prog Histochem Cytochem 42:115-170

59. Gachet C (2008) P2 receptors, platelet function and pharmacological implications. Thromb Haemost 99:466-472

60. Verghese MW, Kneisler TB, Boucheron JA (1996) P2U agonists induce chemotaxis and actin polymerization in human neutrophils and differentiated HL60 cells. J Biol Chem 271:1559715601

61. Sak K, Boeynaems JM, Everaus H (2003) Involvement of P2Y receptors in the differentiation of haematopoietic cells. J Leukoc Biol 73:442-447

62. Chen Y, Shukla A, Namiki S, Insel PA, Junger WG (2004) A putative osmoreceptor system that controls neutrophil function through the release of ATP, its conversion to adenosine, and activation of $\mathrm{A} 2$ adenosine and $\mathrm{P} 2$ receptors. J Leukoc Biol 76:245-253

63. Martel-Gallegos G, Rosales-Saavedra MT, Reyes JP, CasasPruneda G, Toro-Castillo C, Perez-Cornejo P, Arreola J (2010) Human neutrophils do not express purinergic P2X7 receptors. Purinergic Signal 6:297-306

64. Chen Y, Yao Y, Sumi Y, Li A, To UK, Elkhal A, Inoue Y, Woehrle T, Zhang Q, Hauser C, Junger WG (2010) Purinergic signaling: a fundamental mechanism in neutrophil activation. Sci Signal 3:ra45

65. Myrtek D, Idzko M (2007) Chemotactic activity of extracellular nucleotides on human immune cells. Purinergic Signal 3:5-11

66. Warny M, Aboudola S, Robson SC, Sevigny J, Communi D, Soltoff SP, Kelly CP (2001) P2Y(6) nucleotide receptor mediates monocyte interleukin-8 production in response to UDP or lipopolysaccharide. J Biol Chem 276:26051-26056

67. Idzko M, Dichmann S, Ferrari D, Di Virgilio F, la Sala A, Girolomoni G, Panther E, Norgauer J (2002) Nucleotides induce chemotaxis and actin polymerization in immature but not mature 
human dendritic cells via activation of pertussis toxin-sensitive P2y receptors. Blood 100:925-932

68. Bulanova E, Bulfone-Paus S (2010) P2 receptor-mediated signaling in mast cell biology. Purinergic Signal 6:3-17

69. Wang L, Jacobsen SE, Bengtsson A, Erlinge D (2004) P2 receptor mRNA expression profiles in human lymphocytes, monocytes and $\mathrm{CD} 34+$ stem and progenitor cells. BMC Immunol 5:16

70. Ferrari D, Idzko M, Dichmann S, Purlis D, Virchow C, Norgauer J, Chiozzi P, Di Virgilio F, Luttmann W (2000) P2 purinergic receptors of human eosinophils: characterization and coupling to oxygen radical production. FEBS Lett 486:217-24

71. Sluyter R, Barden JA, Wiley JS (2001) Detection of P2X purinergic receptors on human B lymphocytes. Cell Tissue Res 304:231-36

72. Berchtold S, Ogilvie AL, Bogdan C, Mühl-Zürbes P, Ogilvie A, Schuler G, Steinkasserer A (1999) Human monocyte derived dendritic cells express functional $\mathrm{P} 2 \mathrm{X}$ and $\mathrm{P} 2 \mathrm{Y}$ receptors as well as ecto-nucleotidases. FEBS Lett 458:424-28

73. Skelton L, Cooper M, Murphy M, Platt A (2003) Human immature monocyte-derived dendritic cells express the $G$ protein-coupled receptor GPR105 (KIAA0001, P2Y14) and increase intracellular calcium in response to its agonist, uridine diphosphoglucose. J Immunol 171:1941-949

74. Mei L, Du W, Gao W, Mei QB (2010) Purinergic signaling: a novel mechanism in immune surveillance. Acta Pharmacol Sin 31:1149-1153

75. Bours MJ, Swennen EL, Di Virgilio F, Cronstein BN, Dagnelie PC (2006) Adenosine 5'-triphosphate and adenosine as endogenous signaling molecules in immunity and inflammation. Pharmacol Ther 112:358-404

76. Humphreys BD, Dubyak GR (1996) Induction of the P2z/P2X7 nucleotide receptor and associated phospholipase $\mathrm{D}$ activity by lipopolysaccharide and IFN-gamma in the human THP-1 monocytic cell line. J Immunol 157:5627-5637

77. Martin KA, Kertesy SB, Dubyak GR (1997) Down-regulation of P2U-purinergic nucleotide receptor messenger RNA expression during in vitro differentiation of human myeloid leukocytes by phorbol esters or inflammatory activators. Mol Pharmacol 51:97-108

78. Janssen LJ, Farkas L, Rahman T, Kolb MR (2009) ATP stimulates $\mathrm{Ca}(2+)$-waves and gene expression in cultured human pulmonary fibroblasts. Int J Biochem Cell Biol 41:2477-2484

79. Huang NN, Wang DJ, Heppel LA (1993) Stimulation of aged human lung fibroblasts by extracellular ATP via suppression of arachidonate metabolism. J Biol Chem 268:10789-10795

80. Patel GK, Wilson CH, Harding KG, Finlay AY, Bowden PE (2006) Numerous keratinocyte subtypes involved in wound reepithelialization. J Invest Dermatol 126:497-502

81. Santoro MM, Gaudino G (2005) Cellular and molecular facets of keratinocyte reepithelization during wound healing. Exp Cell Res 304:274-286

82. Greig AV, James SE, McGrouther DA, Terenghi G, Burnstock G (2003) Purinergic receptor expression in the regeneration epidermis in a rat model of normal and delayed wound healing. Exp Dermatol 12:860-871

83. Taboubi S, Milanini J, Delamarre E, Parat F, Garrouste F, Pommier G, Takasaki J, Hubaud JC, Kovacic H, Lehmann M (2007) G alpha(q/11)-coupled P2Y2 nucleotide receptor inhibits human keratinocyte spreading and migration. FASEB J 21:40474058

84. Taboubi S, Garrouste F, Parat F, Pommier G, Faure E, Monferran S, Kovacic H, Lehmann M (2010) Gq-coupled purinergic receptors inhibit insulin-like growth factor-I/phosphoinositide 3-kinase pathway-dependent keratinocyte migration. Mol Biol Cell 21:946-955
85. Kaczmarek E, Erb L, Koziak K, Jarzyna R, Wink MR, Guckelberger O, Blusztajn JK, Trinkaus-Randall V, Weisman GA, Robson SC (2005) Modulation of endothelial cell migration by extracellular nucleotides: involvement of focal adhesion kinase and phosphatidylinositol 3-kinase-mediated pathways. Thromb Haemost 93:735-742

86. Yu N, Erb L, Shivaji R, Weisman GA, Seye CI (2008) Binding of the P2Y2 nucleotide receptor to filamin A regulates migration of vascular smooth muscle cells. Circ Res 102:581-588

87. Wang D, Huang NN, Heppel LA (1990) Extracellular ATP shows synergistic enhancement of DNA synthesis when combined with agents that are active in wound healing or as neurotransmitters. Biochem Biophys Res Commun 166:251-258

88. Waldman SD, Usprech J, Flynn LE, Khan AA (2010) Harnessing the purinergic receptor pathway to develop functional engineered cartilage constructs Osteoarthritis. Osteoarthr Cartil 18:864-872

89. Albert JL, Boyle JP, Roberts JA, Challiss RA, Gubby SE, Boarder MR (1997) Regulation of brain capillary endothelial cells by $\mathrm{P} 2 \mathrm{Y}$ receptors coupled to $\mathrm{Ca} 2+$, phospholipase $\mathrm{C}$ and mitogen-activated protein kinase. Br J Pharmacol 122:935-941

90. Cha SH, Hahn TW, Sekine T, Lee KH, Endou H (2000) Purinoceptor-mediated calcium mobilization and cellular proliferation in cultured bovine corneal endothelial cells. Jpn J Pharmacol 82:181-187

91. Satterwhite CM, Farrelly AM, Bradley ME (1999) Chemotactic, mitogenic, and angiogenic actions of UTP on vascular endothelial cells. Am J Physiol 276:H1091-H1097

92. Gendaszewska-Darmach E, Maszewska M, Zaklos M, Koziolkiewicz M (2003) Degradation of extracellular nucleotides and their analogs in HeLa and HUVEC cell cultures. Acta Biochim Pol 50:973-984

93. Erlinge D (1998) Extracellular ATP: a growth factor for vascular smooth muscle cells. Gen Pharmacol 31:1-8

94. Shen J, Seye CI, Wang M, Weisman GA, Wilden PA, Sturek M (2004) Cloning, up-regulation, and mitogenic role of porcine P2Y2 receptor in coronary artery smooth muscle cells. Mol Pharmacol 66:1265-1274

95. Wilden PA, Agazie YM, Kaufman R, Halenda SP (1998) ATPstimulated smooth muscle cell proliferation requires independent ERK and PI3K signaling pathways. Am J Physiol 275:H12091215

96. Seye CI, Yu N, Gonzalez FA, Erb L, Weisman GA (2004) The P2Y2 nucleotide receptor mediates vascular cell adhesion molecule-1 expression through interaction with VEGF receptor2 (KDR/Flk-1). J Biol Chem 279:35679-35686

97. Rumjahn SM, Yokdang N, Baldwin KA, Thai J, Buxton IL (2009) Purinergic regulation of vascular endothelial growth factor signaling in angiogenesis. Br J Cancer 100:1465-1470

98. Hill LM, Gavala ML, Lenertz LY, Bertics PJ (2010) Extracellular ATP may contribute to tissue repair by rapidly stimulating purinergic receptor X7-dependent vascular endothelial growth factor release from primary human monocytes. J Immunol 185:3028-3034

99. Erb L, Liu J, Ockerhausen J, Kong Q, Garrad RC, Griffin K, Neal C, Krugh B, Santiago-Perez LI, Gonzalez FA, Gresham HD, Turner JT, Weisman GA (2001) An RGD sequence in the $\mathrm{P} 2 \mathrm{Y} 2$ receptor interacts with $\alpha \mathrm{V} \beta 3$ integrins and is required for Go-mediated signal transduction. J Cell Biol 153:491-501

100. Hirakawa M, Oike M, Karashima Y, Ito Y (2004) Sequential activation of RhoA and FAK/paxillin leads to ATP release and actin reorganization in human endothelium. J Physiol 558:479 488

101. Koyama T, Oike M, Ito Y (2001) Involvement of rho-kinase and tyrosine kinase in hypotonic stress-induced ATP release in bovine aortic endothelial cells. J Physiol 532:759-769 
102. Woodward HN, Anwar A, Riddle S, Taraseviciene-Stewart L, Fragoso M, Stenmark KR, Gerasimovskaya EV (2009) PI3K, rho, and ROCK play a key role in hypoxia-induced ATP release and ATP-stimulated angiogenic responses in pulmonary artery vasa vasorum endothelial cells. Am J Physiol Lung Cell Mol Physiol 297:L954-L964

103. Gerasimovskaya EV, Woodward HN, Tucker DA, Stenmark KR (2008) Extracellular ATP is a pro-angiogenic factor for pulmonary artery vasa vasorum endothelial cells. Angiogenesis 11:169-182

104. Lyubchenko T, Woodward HN, Veo KD, Burns N, Nijmeh H, Liubchenko GA, Stenmark KR, Gerasimovskaya EV (2011) $\mathrm{P} 2 \mathrm{Y} 1$ and $\mathrm{P} 2 \mathrm{Y} 13$ purinergic receptors mediate $\mathrm{Ca} 2+$ signaling and proliferative responses in pulmonary artery vasa vasorum endothelial cells. Am J Physiol Cell Physiol 300:C266-C75

105. Valls MD, Cronstein BN, Montesinos MC (2009) Adenosine receptor agonists for promotion of dermal wound healing. Biochem Pharmacol 77:1117-1124

106. Gu BJ, Wiley JS (2006) Rapid ATP-induced release of matrix metalloproteinase 9 is mediated by the $\mathrm{P} 2 \mathrm{X} 7$ receptor. Blood 107:4946-4953

107. Gill SE, Parks WC (2008) Metalloproteinases and their inhibitors: regulators of wound healing. Int $\mathrm{J}$ Biochem Cell Biol 40:1334-1347

108. Zhang Y, Gong LH, Zhang HQ, Du Q, You JF, Tian XX, Fang WG (2010) Extracellular ATP enhances in vitro invasion of prostate cancer cells by activating Rho GTPase and upregulating MMPs expression. Cancer Lett 293:189-97

109. Toriseva M, Kahari VM (2009) Proteinases in cutaneous wound healing. Cell Mol Life Sci 66:203-224

110. Hrafnkelsdottir T, Erlinge D, Jern S (2001) Extracellular nucleotides ATP and UTP induce a marked acute release of tissue-type plasminogen activator in vivo in man. Thromb Haemost 85:875-881

111. Bouchie JL, Chen HC, Carney R, Bagot JC, Wilden PA, Feener EP (2000) P2Y receptor regulation of PAI-1 expression in vascular smooth muscle cells. Arterioscler Thromb Vasc Biol 20:866-873

112. Klepeis VE, Weinger I, Kaczmarek E, Trinkaus-Randall V (2004) P2Y receptors play a critical role in epithelial cell communication and migration. J Cell Biochem 93:1115-1133

113. Crooke A, Guzman-Aranguez A, Peral A, Abdurrahman MK, Pintor J (2008) Nucleotides in ocular secretions: their role in ocular physiology. J Pharmacol Ther 119:55-73

114. Pintor J, Bautista A, Carracedo G, Peral A (2004) UTP and diadenosine tetraphosphate accelerate wound healing in the rabbit cornea. Ophthalmic Physiol Opt 24:186-193

115. Weinger I, Klepeis VE, Trinkaus-Randall V (2005) Tri-nucleotide receptors play a critical role in epithelial cell wound repair. Purinergic Signal 1:281-292

116. Mediero A, Peral A, Pintor J (2006) Dual roles of diadenosine polyphosphates in corneal epithelial cell migration. Invest Ophthalmol Vis Sci 47:4500-4506

117. Mayo C, Ren R, Rich C, Stepp MA, Trinkaus-Randall V (2008) Regulation by P2X7: epithelial migration and stromal organization in the cornea. Invest Ophthalmol Vis Sci 49:4384-4391

118. Brunschweiger A, Müller CE (2006) P2 receptors activated by uracil nucleotides - an update. Curr Med Chem 13:289-312

119. Husted S, van Giezen JJ (2009) Ticagrelor: the first reversibly binding oral P2Y12 receptor antagonist. Cardiovasc Ther 27:259-274

120. Yegutkin GG (2008) Nucleotide- and nucleoside-converting ectoenzymes: important modulators of purinergic signalling cascade. Biochim Biophys Acta 1783:673-694 